\title{
Secretory IgA against herpes simplex virus in cervical secretions
}

\author{
ELISABETH PERSSON, * PETER ENEROTH, $\dagger$ STIG JEANSSON $\ddagger$ \\ From the *Department of Obstetrics and Gynaecology, Karolinska Hospital, Stockholm, the †Unit for Applied \\ Biochemistry, The Research Centre, Huddinge Hospital, Stockholm, and the $\ddagger$ Department of Virology, \\ University of Göteborg, Göteborg, Sweden
}

SUMMARY A recently developed method to recover proteins from cervical secretions was combined with methods to detect minute concentrations of herpes simplex virus (HSV) type specific antibodies to measure the concentrations of locally produced antibodies in women with genital infections. Forty nine women attending a sexually transmitted disease (STD) clinic were included. Cervical secretions were obtained by suction into a plastic catheter. Soluble proteins were recovered from the secretions by elution with hyperosmolar sodium chloride. A rabbit antibody to human secretory component, which was conjugated to horseradish peroxidase, was used to measure secretory $\operatorname{IgA}(\mathrm{S}-\operatorname{IgA})$ that was HSV type specific. For comparison, HSV type specific IgG was measured in serum samples from the patients. Of the 49 women, 16 yielded detectable HSV type 2 (HSV 2) S-IgA in secretions. Twelve of them also reacted to the HSV type common antigen, but only five had HSV 2 IgG detectable in their serum. S-IgA against HSV was found in significantly more women with a clinical diagnosis of acute cervicitis than in others. This could be explained by a general increase in local antibody production and immunity triggered by previous contacts with HSV. It is concluded that local mucosal immunity to HSV 2 can be detected in women who do not have a specific humoral antibody response to the virus. For seroepidemiological studies of infection with HSV 2 this local immunity may be considered to be a factor that gives an underestimation of the true incidence of HSV 2 infection.

Infection with herpes simplex virus (HSV) in the genital tract and elsewhere stimulates the production of antibody that is detectable in serum. ${ }^{1}$ Secretory antibodies ( $\mathrm{S}-\mathrm{IgA})$ produced in mucous membranes have been shown to have an active role in the resistance of hosts to viral and bacterial infections. ${ }^{23}$ The presence of mucins in cervical secretions, as well as a lack of tools to detect locally produced antibodies, have hindered the exploration of this secretory immune system.

This investigation aimed to combine recently developed methods to recover proteins from cervical secretions ${ }^{4}$ with methods for detecting minute amounts of HSV type specific antibodies ${ }^{5-7}$ to assess whether antibodies are produced locally in the cervical secretions of women with genital infections.

Patients, materials, and methods

We studied 49 women (median age 22 , range 16-50

Address for reprints: Dr Elisabeth Persson, Department of Obstetrics and Gynaecology, Karolinska Hospital, S-104 01 Stockholm, Sweden

Accepted for publication 13 July 1988 years) who attended a gynaecological clinic with complaints of vaginal discharge. We took careful histories of sexually transmitted diseases (STD) (gonorrhoea, condylomata, trichomoniasis, or infection with chlamydiae or herpes) from the women, and asked whether their sexual partners had any symptoms.

Each patient then underwent pelvic examination. A sample for wet smear analysis was taken from the posterior fornix. All available cervical secretions were then sucked, under visual control, from the cervical canal with a plastic catheter (baby feeding tube, Bardic) attached to a syringe. Material from the cervix and urethra was cultured for Chlamydia trachomatis and from the cervix, urethra, and rectum for Neisseria gonorrhoeae. Cervical material from one patient was cultured for herpes simplex virus. We took $10 \mathrm{ml}$ of blood from all patients for serological analyses.

Thirteen patients returned for a check after one month. The same procedure was performed on that occasion. All clinical sampling was done by one person (EP).

\section{METHODS}

We analysed wet smears for epithelial cells, leucocytes, 
Candida spp, clue cells, and trichomonads. The diagnosis of acute cervicitis relied on clinical findings and wet smear analysis (showing more leucocytes than epithelial cells). We performed cultures according to clinical routines. We stored the serum samples and secretions at $-20^{\circ} \mathrm{C}$ until they were analysed.

\section{Recovering soluble proteins from cervical secretions}

Soluble proteins were recovered from the secretions using a method developed by Fleetwood et al. ${ }^{4}$ To each thawed sample we added $1 \mathrm{ml}$ of $0.66 \mathrm{~mol} / 1$ sodium chloride. We eluted the proteins through a column of washed seasand by adding another $3 \mathrm{ml}$ sodium chloride. After recovery and before further analyses the samples were lyophilised and dissolved in aliquots of sterile water.

\section{Detecting HSV type specific $S-\operatorname{Ig} A$ in secretions}

We performed an enzyme linked immunosorbent assay (ELISA) for HSV 2 type specific antibodies as described previously by Olofsson et al. ${ }^{6}$ An antigen with strong intertypic reactivity was used to measure HSV type common antibodies. ${ }^{5}$ We used a rabbit antibody to human secretory component, which was conjugated to horseradish peroxidase (HRP), to measure secretory antibodies. ${ }^{8}$ In controlled studies, using this conjugate in an ELISA with samples of breast milk and serum from patients immunised with oral cholera vaccine, ${ }^{9}$ secretory antibodies against cholera could be detected in breast milk only, whereas no antibodies were detectable in serum. In similar studies of patients with recurrent oral infection with HSV, secretory antibodies against HSV could be detected in saliva only, and not in serum.

The optimum dilution of the conjugate was assessed, and in all experiments the conjugate was used diluted $1 / 50$. This conjugate was only used to measure antibodies in secretions. ${ }^{111}$ Secretions were tested starting from a $1 / 50$ dilution.

\section{Detecting HSV type specific IgG in serum}

Serum samples were tested in twofold dilution steps of a 1/100 dilution. Alkaline phosphatase conjugated heavy chain specific swine antibodies to human IgG (Orion Diagnostika, Helsinki, Finland) were used in a dilution of $1 / 150$ to detect IgG antibodies in serum.

\section{Statistical method}

For statistical analysis the $\chi^{2}$ method was used.

\section{Results}

Of the 49 women, 19 had histories of STDs ( 11 had had chlamydial infections, five gonorrhoea, and three condylomata). Three had histories of genital herpes, one of whom had had recurrences once every two
Table 1 Clinical diagnoses, culture results, and history of sexually transmitted disease (STD) in 49 women with vaginal discharge

\begin{tabular}{lr}
\hline & No \\
\hline Clinical diagnosis: & \\
Acute cervicitis & 23 \\
Vulvovaginitis & 11 \\
Bacterial vaginosis & 10 \\
Healthy & 5 \\
Chlamydial infection & 22 \\
Gonococcal infection & 0 \\
History of or current STD & 39 \\
No history of or current STD & 10 \\
\hline
\end{tabular}

months for two years. None of these three women had symptoms or signs of current genital herpes infection at examination.

Table 1 shows that 23 women had a clinical diagnosis of acute cervicitis, 11 of candidal vulvovaginitis, 10 bacterial vaginosis, and five were healthy. Culture results showed that 22 women had chlamydial infection, of whom 12 also had a clinical diagnosis of cervicitis. No gonococci were isolated. HSV 2 was isolated from the cervix of one patient. Altogether 39 women had histories of, or current, STD (including cervicitis); the other 10 had neither histories of nor current STD.

Table 2 shows the titres of S-IgA against HSV type common and HSV 2 antigen in cervical secretions. Of 16 women in whom HSV 2 antibodies were detectable at a titre of $1 / 50$ or more, 12 also reacted with the HSV type common antigen.

Of the 49 patients, $35(71 \%)$ had HSV type common IgG antibodies and $15(31 \%)$ had HSV 2 IgG. All women in the latter group also had HSV type common IgG. Table 3 shows the relations between antibodies against the respective type of HSV antigen in serum and secretions. In women with antibody against HSV type common antigen the only pattern found was that high titres of S-IgA $(1 / 100)$ related to high titres of IgG in serum. No such correlation was found in women with antibodies specific to HSV 2; in fact all five women with S-IgA at a titre of $1 / 100$ or more had low titres (less than 1/200) of IgG in their serum.

Table 2 Secretory IgA (S-IgA) against HSV type common and $H S V 2$ antigen in cervical secretions from 49 women with vaginal discharge

\begin{tabular}{lll}
\hline Titre of S-IgA & $\begin{array}{l}\text { HSV type } \\
\text { common antigen }\end{array}$ & $\begin{array}{l}\text { HSV 2 } \\
\text { antigen }\end{array}$ \\
\hline$<1 / 50$ & 30 & 33 \\
$1 / 50$ & 14 & 11 \\
$1 / 100$ & 5 & 3 \\
$1 / 200$ & 0 & 1 \\
$1 / 400$ & 0 & 1 \\
\hline
\end{tabular}


Table 3 Relations between type specific antibodies against HSV type common antigen and HSV 2 antigen in serum (IgG) and secretions ( $S$ - $\operatorname{Ig} A$ ) from 49 women with vaginal discharge

\begin{tabular}{|c|c|c|c|c|}
\hline \multirow{2}{*}{$\begin{array}{l}\text { Titres of secretions } \\
\text { containing } \operatorname{Ig} A\end{array}$} & \multicolumn{4}{|c|}{ No with serum IgG at titres of } \\
\hline & $<1 / 100$ & $1 / 100-1 / 200$ & $1 / 400-1 / 800$ & $1 / 1600-1 / 3200$ \\
\hline $\begin{array}{c}\text { HSV type common } \\
<1 / 50 \\
1 / 50 \\
1 / 100\end{array}$ & $\begin{array}{r}11 \\
3 \\
0\end{array}$ & $\begin{array}{l}2 \\
2 \\
0\end{array}$ & $\begin{array}{l}8 \\
3 \\
4\end{array}$ & $\begin{array}{l}9 \\
6 \\
1\end{array}$ \\
\hline $\begin{array}{l}\text { HSV } 2 \text { antigen: } \\
<1 / 50 \\
1 / 50 \\
1 / 100 \\
1 / 200 \\
1 / 400\end{array}$ & $\begin{array}{r}23 \\
7 \\
3 \\
0 \\
1\end{array}$ & $\begin{array}{l}0 \\
3 \\
0 \\
1 \\
0\end{array}$ & $\begin{array}{l}7 \\
0 \\
0 \\
0 \\
0\end{array}$ & $\begin{array}{l}3 \\
1 \\
0 \\
0 \\
0\end{array}$ \\
\hline
\end{tabular}

Table 4 shows the clinical findings related to the occurrence of S-IgA against the two virus antigens. We found significantly more S-IgA against both HSV type common $(p=0.01)$ and HSV $2(p=0.006)$ antigens in cervical secretions from women with a clinical diagnosis of cervicitis than women with other clinical diagnoses. No difference was found between patients who had or did not have chlamydial infection or histories of or current STD.

Five samples of secretions contained S-IgA against HSV type common antigen at a titre of $1 / 100$ or more, and five contained antibodies against HSV 2 (table 2). These samples were from six patients, all of whom had a clinical diagnosis of cervicitis, and three of whom yielded $C$ trachomatis from their cervices. One of the six patients (case 1) had a history of genital herpes.

All three patients (cases 1,2, and 3) with clinical histories of genital herpes infection had high titres of IgG against HSV type common antigen. Two (cases 2 and 3) also had high titres of serum antibodies against HSV 2, whereas one (case 1) had a negative result. Titres of S-IgA against HSV type common antigen were low in secretions from all three, whereas one (case 1) had a high titre (1/400) against HSV 2 . She had chlamydial cervicitis, the other two had candidiasis.

The 12 patients with chlamydial cervicitis had a check up examination after one month, as did the patient (case 4) with HSV 2 cervicitis. All chlamydia positive patients had been treated with tetracyclines for 10 days, and their partners had been investigated and treated. None of the patients had any symptoms or signs of genital infection at check up examination, and material for chlamydial cultures taken then gave negative results. All 13 patients had stable serological antibody titres against HSV type common antigen. When comparing IgG against HSV 2 antigen the titres of 11 were stable, whereas two women showed a twofold or more change. One of the two (case 4) had severe herpetic cervicitis and bilateral lymphadenopathy. HSV 2 was isolated from her cervix. All other cultures gave negative results. In the acute phase she had serum IgG titres of $1 / 400$ against HSV 2 , and these fell to below levels of detection at her follow up visit. Her S-IgA titres were low (1/50) and showed no change during the observation period. The other woman (case 1) had chlamydial cervicitis and a history of genital herpes two years previously, but had had no known recurrences since then. In the acute phase no antibodies against HSV 2 antigen were detected in her serum, but S-IgA against HSV 2 was found at titres of $1 / 400$ in her secretions. After one month her HSV 2 IgA titres had fallen to $1 / 50$, whereas serum titres for HSV 2 IgG had risen to $1 / 200$. Her antibody titres against HSV type common antigen in serum $(1 / 400)$ and secretions $(1 / 50)$ remained the same.

Another three patients showed significant changes

Table 4 Secretory $\operatorname{IgA}(S-\operatorname{IgA})$ against HSV type common antigen and HSV 2 antigen related to clinical findings of 49 women with vaginal discharge

\begin{tabular}{|c|c|c|c|c|c|c|}
\hline \multirow[b]{2}{*}{ Clinical findings } & \multicolumn{3}{|c|}{$S$-IgA against HSV type common antigen } & \multicolumn{3}{|c|}{$S$-IgA against $H S V 2$ antigen } \\
\hline & Positive & Negative & Difference & Positive & Negative & Difference \\
\hline $\begin{array}{l}\text { Acute cervicitis } \\
\text { Other clinical diagnosis }\end{array}$ & $\begin{array}{r}13 \\
6\end{array}$ & $\begin{array}{l}10 \\
20\end{array}$ & $p=0.01$ & $\begin{array}{r}12 \\
4\end{array}$ & $\begin{array}{l}11 \\
22\end{array}$ & $p=0.006$ \\
\hline $\begin{array}{l}\text { Current chlamydial infection } \\
\text { No current chlamydial infection }\end{array}$ & $\begin{array}{r}11 \\
8\end{array}$ & $\begin{array}{l}11 \\
19\end{array}$ & NS & $\begin{array}{l}7 \\
9\end{array}$ & $\begin{array}{l}15 \\
18\end{array}$ & NS \\
\hline $\begin{array}{l}\text { History of or current STD } \\
\text { No history of or current STD }\end{array}$ & $\begin{array}{r}17 \\
2\end{array}$ & $\begin{array}{r}22 \\
8\end{array}$ & NS & $\begin{array}{r}14 \\
2\end{array}$ & $\begin{array}{r}25 \\
8\end{array}$ & NS \\
\hline
\end{tabular}


in secretory antibody titres against HSV 2 . One (case 5) had mucopurulent cervicitis caused by $C$ trachomatis, but no history of herpes virus infection. She showed threefold increases in S-IgA against HSV 2 and HSV type common antigens, but results of tests for serum IgG remained negative. Two patients (also with chlamydial cervicitis) showed twofold decreases in $\mathrm{S}-\operatorname{IgA}$, but stable serum titres.

\section{Discussion}

In this investigation a new approach was used to assess the occurrence and concentrations of locally produced type specific antibodies against HSV 2 in the genital tracts of women. The prerequisite conditions for this were the recently developed methods for recovering immunoglobulins from cervical secretions ${ }^{4}$ and for detecting minute amounts of HSV type specific secretory antibodies. ${ }^{56}$ The method for separating the proteins from the mucins in the secretions is simple and has been shown to give almost $100 \%$ recovery rates. ${ }^{4}$ Other workers have used filter paper strips combined with immunofluorescence tests to detect antibodies. ${ }^{12}$ The methods used in this study design, however, permit the recovery of more proteins and give less bias in interpretations.

When considering the results, the distinction between the two types of herpes virus antigens used to measure herpes virus antibodies must be clear. The antigen to detect HSV 2 S-IgA and IgG antibodies is type specific and does not cross react with HSV 1 . The HSV type common antigen used in the ELISA cross reacts and will detect antibodies against both HSV 1 and HSV $2 .^{5-7}$

HSV 2 is reported to be the causative organism in $80-90 \%$ of first episodes of genital herpes. HSV 2 infection is also much more likely to recur than HSV 1 infection, but the reasons are not known. ${ }^{13}$ Twelve of the 16 women who had HSV 2 specific antibodies in secretions also had HSV type common antibodies. In view of the different incidences of HSV 1 and HSV 2 in genital infections the reactions against HSV type common antigen in these women are probably explained by an antibody response against HSV 2 (table 2).

Only seven patients had S-IgA against HSV type common antigen only. This group accounted for $30 \%$ of the women with a positive secretory HSV antibody test result. The antibodies detected could have been directed against HSV 1 or HSV 2.

We found IgG antibodies against HSV type common antigen in $71 \%$ and HSV 2 antigen in $31 \%$ of the 49 serum samples. All women with antibodies against HSV 2 antigen also had antibodies against HSV type common antigen. These incidences are the same as have been found in screening tests of patients attend- ing STD clinics and prenatal clinics in Sweden (A Nahmias, personal communication). Only three patients, however, gave a history of genital herpes infection. HSV antibodies were detected in the serum from all three. A comparison between HSV 2 specific S-IgA and serum IgG titres (table 3 ) shows that patients with high titres of S-IgA were found to have low titres or not even detectable levels of IgG and vice versa. This indicates the possibility of a local immune response in the genital tract without detectable stimulation of the humoral antibody system. The high titres of serum IgG against HSV type common antigen in women without detectable S-IgA can be explained by the fact that extragenital HSV 1 infections are common. ${ }^{14}$

When women with different clinical diagnoses were compared for the presence of S-IgA against HSV, SIgA was detected in more women with acute cervicitis than with other diagnoses (table 4). Cervical secretion is stimulated in patients with acute cervicitis as part of the defence reactions. The higher incidence of antibodies to HSV in secretions from these women could be explained by a general increase in local antibody production and by immunity triggered by previous contacts with HSV. This theory is supported by the stable concentrations of serum antibodies in samples taken from women after their cervicitis had been cured and by the stability of or decrease in S-IgA titres in most women at follow up.

In this study no routine cultures for HSV were undertaken. Current herpes infection of the cervix was therefore not excluded. Other workers have, however, found an inverse relation between S-IgA against HSV 2 and the isolation of the virus. ${ }^{12}$ This accords with our findings in one patient (case 4) who was diagnosed as having a primary HSV 2 infection. She had IgG against HSV 2 at a titre of $1 / 400$ in the acute phase, whereas titres of S-IgA were low (1/50). At follow up her serum concentrations had fallen and her S-IgA titres remained low.

High concentrations of S-IgA may be expected early in patients with recurrent HSV cervicitis. Recurrences of HSV 2 infection could explain the high concentrations of S-IgA against HSV 2 in case 1 in the acute phase and in case 5 at follow up. Serum antibodies were detected at follow up of case 1 , which indicated a slower reactivity of the humoral antibody response.

More than half the women with cervicitis had chlamydial infection. No relation was found between the absence or presence of $C$ trachomatis and the detection of local antibodies to HSV, which showed that there was no cross reactivity between the organisms.

No correlation was found between $\mathrm{S}-\operatorname{IgA}$ and past or present STD. More women with genitally produced antibodies might be expected to give histories of HSV 
infection or at least other more overt STDs. Though 15 women had serum IgG against HSV 2, however, only three gave a history of genital herpes infection. A history is thus apparently not a sensitive enough tool to find women with genital herpes infections.

In conclusion, a combination of two methods was tested and found to be useful for detecting locally produced antibodies against HSV type common antigen and HSV 2 antigen. A high incidence of HSV specific S-IgA was found in women with a clinical diagnosis of cervicitis. Further clinical studies are needed to elucidate the functional importance of this immune response. A new and interesting finding is that pronounced local mucosal immunity may correspond to a lack of humoral antibody response. For seroepidemiological studies of HSV 2 infection this may be considered to be a factor that gives an underestimation of the true incidence of HSV 2 infection.

\section{References}

1 Mindel A, Sutherland S. Genital herpes-the disease and its treatment including intravenous acyclovir. $J$ Antimicrob Chemother 1983;12 suppl B:51-9.

2 Kearns DH, O'Reilly RJ, Lee L, Welch BG. Secretory IgA antibodies in the urethral exudate of men with uncomplicated urethritis due to Neisseria gonorrhoeae. J Infect Dis 1973; 127:99-101.

3 Rebello R, Green FHY, Fox H. A study of the secretory immune system of the female genital tract. Br J Obstet Gynaecol 1975; 82:812-6.
4 Fleetwood L, Landgren BM, Eneroth P. A method for isolation, : characterization and quantitation of soluble proteins in uterine cervical secretions. Gynecol Obstet Invest 1984;17:40-6.

5 Jeansson S, Elwing H, Nygren H, Olofsson S. Evaluation of solubilized herpes simplex virus membrane antigens in gelenzyme-linked immunosorbent assay (DIG-ELISA). $J$ Virol Methods 1982;4:167-76.

6 Olofsson S, Lundström M, Marsden H, Jeansson S, Vahine A. Characterisation of a herpes simplex virus type 2-specified glycoprotein with affinity for $\mathrm{N}$-acetylgalactosamine-specific lectin and its identification as $\mathrm{g} 92 \mathrm{~K}$ or $\mathrm{gG}$. J Gen Virol 1986;67:737-44.

7 Jeansson S, Forsgren M, Svennerholm B. Evaluation of solubilized herpes simplex virus membrane antigen by enzymelinked immunosorbent assay. J Clin Microbiol 1983;18:1160-6.

8 Wilson MB, Nakane PK. Recent developments in periodate method of conjugating horseradish peroxidase (HRP) to antibodies. In: Knapp W, Holubar K, Wick G, eds. Immunofluorescence and related techniques. Amsterdam: Elsevier, 1978; 215-24.

9 Jertborn M, Svennerholm A-M, Holmgren J. Saliva, breast milk, and serum antibody responses as indirect measure of intestinal immunity after oral cholera vaccination or natural disease. J Clin Microbiol 1986;24:203-9.

10 Fox PD, Khaw PT, McBride BW, McGill JI, Ward KA. Tear and serum antibody levels in ocular herpetic infection: diagnostic precision of secretory IgA. Br J Ophthalmol 1986;70:584-8.

11 Losowsky MS, ELISA for measurement of secretory IgA distinct from monomeric IgA. J Immunol Methods 1978;97:269-74.

12 Merriman H, Woods S, Winter C, Fahnlander A, Corey L. Secretory IgA antibody in cervicovaginal secretions from women with genital infection due to herpes simplex virus. $J$ Infect Dis 1984;149:505-10.

13 Corey L, Adams HG, Brown ZA, Holmes KK. Genital herpes simplex virus infections: clinical manifestations, course, and complications. Ann Intern Med 1983;98:958-72.

14 Zachariae H. Herpes virus infection in man. Scand J Infect Dis 1985;47 suppl:44-50. 